REGARDS

SUR L'ECONOMIE ALLEMANDE

BULLETIN ECONOMIQUE DU CRAC

\section{Regards sur l'économie allemande}

Bulletin économique du CIRAC

115 | 2014

Varia

\title{
Décès de Karl-Otto PÖHL († 09-12-2014)
}

\section{Isabelle Bourgeois}

\section{OpenEdition}

\section{Journals}

Édition électronique

URL : http://journals.openedition.org/rea/4770

DOI : 10.4000/rea.4770

ISSN : 1965-0787

Éditeur

CIRAC

Édition imprimée

Date de publication : 1 décembre 2014

Pagination : 38

ISSN : 1156-8992

\section{Référence électronique}

Isabelle Bourgeois, « Décès de Karl-Otto PÖHL († 09-12-2014)», Regards sur l'économie allemande [En ligne], 115 | décembre 2014, mis en ligne le 01 décembre 2016, consulté le 15 septembre 2020. URL http://journals.openedition.org/rea/4770

Ce document a été généré automatiquement le 15 septembre 2020.

(c) CIRAC 


\title{
Décès de Karl-Otto PÖHL († 09-12-2014)
}

\author{
Isabelle Bourgeois
}

1 "L'inflation est comme le dentifrice", il faut éviter de trop appuyer sur le tube car on ne peut y faire rentrer ce qui en est sorti. Cette métaphore, formulée par Karl-Otto Pöhl lors de sa prise de fonction à la tête de la Bundesbank (il la présida de 1980 à 1991), résume bien son profond engagement pour la stabilité monétaire. Il s'est opposé à un chancelier Schmidt qui jugeait la politique de la Buba trop restrictive et préférait recourir au traitement social du chômage grâce à des programmes d'investissements publics. Il s'est opposé au chancelier Kohl lors de l'union monétaire allemande, considérant que le taux de change de 1 DM contre 1 mark est était disproportionné, et a vertement critiqué ensuite le recours massif à la dette par le gouvernement Kohl, avant de démissionner. K.-O. Pöhl était l'incarnation même de l'indépendance de la Buba. Et l' un des principaux artisans de l'indépendance de la BCE dont les statuts ont été élaborés sous sa houlette conjointement avec ses homologues dans la future zone Euro - son ' chef-d'œuvre'. Apprécié pour sa rigueur intellectuelle autant que son sens de l'humour et sa capacité à décrire avec simplicité des réalités complexes, K.-O. Pöhl (né à Hanovre en 1929) était journaliste économique, puis directeur des publications de l'institut ifo de Munich avant d'exercer ces fonctions. Membre du SPD depuis 1948, il avait rendu sa carte en 2005, ne se reconnaissant plus dans un parti qui, perdant de vue l'essentiel, se cantonne aujourd'hui aux "poncifs sur la justice sociale » et les acquis sociaux.

\section{INDEX}

Mots-clés : expertise économique, finances publiques, gouvernance, inflation 